\title{
CORRELATION BETWEEN THE AIR QUALITY INDEX SAQI_11 AND SUSTAINABLE RURAL DEVELOPMENT IN THE REPUBLIC OF SERBIA
}

\author{
Milan Počuča ${ }^{1}$, Jelena Matijasevic - Obradovic ${ }^{2}$, Bojana Draskovic ${ }^{3}$
}

\begin{abstract}
The air quality, in general, has an important impact on the development of rural areas, and sustainable rural development. Air quality is a very important parameter both for sustainable rural development and for life on earth in general. In this context, it is interesting to analyze the correlation between sustainable rural development and the state of air quality dependent on the amount of pollutant concentration, expressed by the air quality index SAQI_11. The main attention in the research was focused on the analysis of the numerical values of pollutants concentrations, for the period of averaging - 24 h and the calendar year, in accordance with the classes of the Air Quality Index SAQI_11, and the analysis of the air quality trend by zones and agglomerations for the period 2012-2015. Conclusions on air quality, SAQI_11 air quality index classes, and on correlation with sustainable rural development were carried out for agglomerations "Novi Sad", "Belgrade”, "Pančevo", "Smederevo”, "Bor", "Kosjerić”, "Uziče" and "Nǐ̌ ".
\end{abstract}

Key words: air quality, SAQI_11, pollutants, sustainable rural development.

JEL: $Q 01, Q 15, Q 56,013,018$

\section{Introduction}

The concept of sustainable rural development began to be applied in the eighties of the last century. On its basis, it is interactively connected and conditioned by the trend of reducing the poverty of underdeveloped regions on the world level.

According to some authors, rural poverty, not developmental disparities, conditions the necessity of rural development policy. These authors see rural underdevelopment as the basic factor of total underdevelopment of less developed countries (Bogdanov, 2007). As

1 Milan Počuča Ph.D., Full professor, Faculty of Law for Commerce and Judiciary in Novi Sad, Geri Karolja Street no. 1, 21000Novi Sad, Serbia, E-mail: pocucabmilan@gmail.com

2 Jelena Matijašević-Obradović Ph.D., Associate professor, Faculty of Law for Commerce and Judiciary in Novi Sad, Geri Karolja Street no. 1,21000Novi Sad, Serbia, E-mail: jela sup@yahoo.com

3 Bojana Drašković Ph.D., Assistant professor, Faculty for construction menagement, Cara Dušana Street no. 62-64, Belgrade, Serbia, E-mail: bodraskovic@gmail.com

EP 2017 (64) 3 (1249-1262) 
part of the promotion of sustainable agriculture and rural development, emphasis is placed primarily on environment, rural development, communication in development, education, local population (local participants), science and technology (Simonović, 2008).

Rural development was created as a response to problems related to intra and inter regional inequalities in the level of economic development and served as a (appropriate) concept for more complex valorisation of the development potentials of rural areas (Bogdanov, 2003). Bearing in mind that as many as $75 \%$ of the world's poor live in rural areas and more than one third of rural areas are in arid and semiarid regions (Chaudhry, Gupta, 2010), it can certainly be assumed that "by introducing new non-agricultural activities (especially rural tourism), additional income can be created which will enable improvement of the quality of life and stopping the demographic decline in rural areas" (Popesku, 2008). Also, rural tourism is expected to act as one of the tools for sustainable rural development (Ivolga, 2014).

Rural areas in Serbia occupy about $85 \%$ of the territory inhabited by more than half of the total population (55\%), with a population density of 63 inhabitants per square kilometre (according to the OECD, the area of up to 150 inhabitants per $\mathrm{km} 2$ is considered rural). Most of the country's natural resources (agricultural land, forests, water) with rich ecosystems and biodiversity are located in rural areas. According to the Strategy of Agriculture and Rural Development of the Republic of Serbia for the period 20142024. (Official Gazette of the Republic of Serbia, No. 85/2014), the positive shift made in organic production, wine production, products with geographical origin and agro tourism in previous years are emphasized.

Rural development on its basis includes the agrarian, but also the non-agrarian sector in rural areas, thus encompassing every vital component of the development of rural areas (economic, environmental, social, cultural, demographic, etc.). According to Bogdanov, the need for rural politics, equally in the developed and underdeveloped countries, stems from the different nature of the impact and intensity of poverty in rural and urban areas, which causes consequences in terms of degradation of the natural environment and negative economic and social implications on the metropolitan areas (Bogdanov, 2007). Generally, air quality has an important impact on development of rural areas, as well as on sustainable rural development. In this context, it is interesting to analyze the correlation between sustainable rural development and the state of air quality dependent on the amount of pollutant concentration, expressed by the air quality index SAQI_11.

Accordingly, in the work, following the relevant theoretical views, within the research work, attention will be focused on key issues in the field of air quality impacts caused by the concentration of pollutants in sustainable rural development. The main attention in the research will be focused on the analysis of numerical values of pollutants concentrations, for the period of averaging - 24h and the calendar year, according to the classes of the Air Quality Index SAQI_11, and on the analysis of the air quality trend by zones and agglomerations for the period 2012-2015. 


\section{Literature review}

One of the important features of modern society is focus on sustainable development (Šimkova, 2007). Sustainability can simply be described as continuing to improve human wellbeing, whilst not undermining the natural resource base on which future generations will have to depend (Adinyira, Oteng-Seifah, Adjei-Kumi, 2007). Sustainable development, as a modern development concept which harmonizes the social, economic and ecological interests of present and future generations, is very applicable in rural areas, which is confirmed both in theory and in practice, especially in developed countries (Ristić, 2013).

Rural tourism and agrotourism could lead a new relationship between environment, work and free time, in terms of sustainability of rural areas (Perotto, 1993; Fagioli, Diotallevi, Ciani, 2014). On the one hand tourism has a great impact on the development of rural areas, and on the other hand, the importance of tourism is reflected in the creation of markets for agricultural products, given that they are important inputs for hotels and restaurants (Ćirić, Počuča, Raičević, 2014). Ruralni turizam, as an essential factor in the revitalization and diversification of rural economy (Ristić, Vujičić, Leković, 2016), is based on the principles of sustainability and includes a range of activities and services that the rural population organize precisely on the basis of the elements which characterize these rural areas (ĐorđevićMilošević, Milovanović, 2012). But, surely, agriculture, as the primary industry in rural areas, is the major (and often the only one) source of employment and income for rural people (Erokhin, 2014). Hence, rural development is considered as a complex mesh of networks in which resources are mobilized and in which the control of the process consists of interplay between local and external forces (Lowe, Murdoch, Ward, 1995; Papić, Bogdanov, 2015).

Rural areas are marked by a number of physical and socio-economic features including: low density of population and development, landscape predominated by open green spaces, "surface" economic activity mainly of agricultural and forestry functions, lifestyle of residents predetermined by affiliation to a small social group and identify and appearance of the population deeply rooted in distinctive peasant culture (Chmielinski, Chmielewska, 2015). Rural areas in Serbia are highly diverse in terms of natural endowments, economic, social and population characteristics. Diversity of rural areas is driven by natural resource endowments, cultural and historical heritage, as well as economic, social and demographic patterns (Papić, Bogdanov, 2015). Rural areas are usually associated with farmlands and farms, as well as a place to stay for a summer holiday or to go to for a weekend trip (Chmielinski, Chmielewska, 2015). Nowadays, predominant opinion is that a rural region represents a territorial unit with one or more small/middle-sized towns surrounded by a large area of open space, with a relatively low population density and regional economic structure, which reflects the situation of a certain labour market (Bogdanov, Stojanovic, 2006).

From its beginnings in economics and ecological thinking, sustainability has become a planning concept and has been widely applied in rural development (Adinyira et al., 2007). Most rural research and practice in Europe focus on endogenous relations (multi-functional agriculture, rural entrepreneurs, improved living conditions in rural areas, local amenities etc.) as the way of securing development or just a pleasant life for the actual inhabitants (Just, 
2007). Rural sustainability is best attained through well-planned and properly implemented initiatives that address the social, physical and economic facets of the environment in an integrated and participatory approach (Sandham, Van Der Walt, 2004). Obviously, living and working in rural areas has always been connected with specific material and symbolical relations to nature (Molders, 2013; Milbourne, 2003; Castree, Braun, 2006). Popesku states that sustainable rural development includes the following principles: environmental, social, cultural and economic (Popesku, 2011). In other words, sustainable rural development means respect for the natural diversity of a destination (environmental principle), protection of the cultural diversity of the local community, and discouragement of the forms of tourism that contribute to social problems (social principles), the development of tourism characteristic for a particular area, and promotion of the unique characteristic of culture and the heritage of the area (cultural principles), stimulation of the employment of the local population, the prevention of the disappearance of the traditional vocations, as well as the promotion of the use and sale of local food products.

Simply put, rural development is about implementing a political, economic and social project attuned to a collective vision of the future of rural regions (Yves, 2005). So, according to Kačar, Curić, Ikić (2016), rural, and particularly local, development could be observed through the regional economy prism as well as from a point of view of multidiscipline rural studies, and not only trough basic economic development theories. It can be concluded that the sustainable development of rural tourism must be economically justified while preserving the natural, social and cultural characteristics of the tourist destination.

Namely, the versatile rural development implies demographic reconstruction, the use of available resources for the production of healthy food, the development of non-agricultural activities, urbanization in terms of infrastructure development, education, culture and preservation of the ecological environment. Especially important is the concept of development of farm, small and medium enterprises, agro-production and agro-processing, rural tourism, service provision activities of business cooperatives and advisory services (Veselinović, Ignjatijević, 2013).

\section{Methodology and data sources used}

The subject of the analysis in the work is the key issues in the field of air quality impacts caused by the concentration of pollutants in sustainable rural development. The main attention in the research will be focused on analyzing the numerical values of concentrations of pollutants, for the period of averaging - $24 \mathrm{~h}$ and the calendar year, according to the classes of the Air Quality Index SAQI_11.

In the theoretical part of the work, the method of theoretical analysis of contents was primarily applied with the basic methods of concretization and specialization, while statistical and analytical-deductive methods were used in the research part, as well as the method of quantitative data analysis.

The survey is based on the official statistics of the Statistical Office of the Republic of Serbia and the Environmental Protection Agency of the Ministry of Agriculture and Environmental Protection. 


\section{Research results and discussion}

In the context of previously stated attitudes, it can be said that sustainable development actually implies an integral view of the life and work of a modern person, while the indicators of sustainable development in general indicate the link between the economy, ecology and society of a particular community. According to Veljković, the essence of the concept of sustainable development is interaction between development and the environment and the mutual conditionality and complementarity of developmental and environmental protection policies that respect the laws of ecological systems (Veljković, 2017). Air quality is a very important parameter for both humans and the whole living world on earth. The air quality indicators are as follows: air temperature, direction and intensity of air currents, baseline level of ozone, nitrogen dioxide level, level, structure and size of fine particles, benzene level, level of other chemical substances, changes of stratospheric ozone and increase in ultraviolet radiation (Kokić Arsić, Milivojević, Savović, 2009). According to the National Strategy for Sustainable Development (Official Gazette of RS, No. 57/2008), the quality of ambient air in urban areas is conditioned by the emissions of SO2, NOx, SO, soot, powder, organic and inorganic materials derived from thermal power stations, industry, traffic, combustion in individual boiler rooms, etc. Large polluters are thermal power stations in Obrenovac, Kolubara and Kostolac, refineries in Pančevo and Novi Sad, chemical industry and metallurgical complexes located in Pančevo, Kruševac, Šabac, Bor and Smederevo. As a result of the concentration of petrochemical and refinery complexes and nitrogen, there is cumulative air pollution in Pančevo. The quality of air in urban areas is conditioned by the increase in the number of motor vehicles and industrial production, as well as the type and number of sources of pollution. Much air pollution comes from the use of gasoline with the addition of lead and diesel with a high sulphur percentage.

The effect of the greenhouse is related to the increase of $\mathrm{CO} 2$ and methane in the atmosphere, and the biggest polluters by sectors are: energy, agriculture, transport, industry (industrial processes), waste, changes in the use of land and forest - logging (Kokić Arsić et al., 2009).

In accordance with the Article 5 of the Law on Air Protection (Official Gazette of RS, No. 36/2009 and 10/2013), the Decree on the Determination of Zones and Agglomerations (Official Gazette of the Republic of Serbia, No. 58/11 and 98/12) on the territory of the Republic of Serbia have been determined three zones and eight agglomerations (Popović et al., 2016; Popović et al., 2015; Popović et al., 2014; Popović et al., 2013) : Zone: 1.) The "Serbia" zone, which includes the territory of the Republic of Serbia except the territory of the autonomous provinces, the city of Belgrade, the city of Niš, the city of Užice, the city of Smederevo, the municipality of Kosjerić and the municipality of Bor; 2.) "Vojvodina" zone, which includes the territory of the Autonomous Province of Vojvodina, except the territory of the cities of Novi Sad and Pančevo; 3.) The "Kosovo and Metohija" zone, which includes the territory of the Autonomous Province of Kosovo and Metohija. Agglomerations: 1.) Agglomeration "Belgrade" (territory of the city of Belgrade); 2.) Agglomeration "Novi Sad" (territory of the city of Novi Sad); 3.) Agglomeration "Niš" (the territory of the city of Niš); 4.) Agglomeration "Bor" (territory of Bor municipality); 5.) Agglomeration "Uzice" (territory of the city of Uzice); 6.) Agglomeration Kosjerić (territory of Kosjerić Municipality); 7.) 
Agglomeration "Smederevo" (the territory of the city of Smederevo); 8.) Agglomeration "Pančevo" (the territory of the town of Pančevo).

The assessment of air quality, based on the measured concentrations of pollutants in the air, is carried out using the criteria for the assessment of air quality, in accordance with the Regulation on the conditions for monitoring and air quality requirements (Službeni glasnik RS, br, 11/2010, 75/2010 i 63/2013) (Popović et al., 2016).

In accordance with Article 3 of the Regulation on conditions for monitoring and air quality requirements (hereinafter: the Regulation), air quality requirements are, inter alia: The limit values of the level of pollutants in the air; The upper and lower limits for assessing the level of pollutants in the air; The limits of tolerance and tolerant values; Concentrations dangerous to human health; Critical levels of pollutants in the air, etc. Article 7 of the Regulation, regulates that the level of air pollution is monitored by measuring the concentrations for sulfur dioxide, nitrogen dioxide and nitrogen oxides, suspended particles (PM10, PM2.5), lead, benzene, carbon monoxide, terrestrial ozone, arsenic, cadmium, Nickel and benzo (a) pyrene in the air by instruments for automatic measurement and / or sampling and their analysis. Air quality monitoring is also carried out at basic rural locations outside the direct impact of significant sources of air pollution to provide at least minimum information on the total mass concentration and the chemical composition of suspended particles (PM2.5) based on the annual average (Article 9 of the Regulation). Boundary and tolerant values are the basis for: 1) air quality assessment; 2) division of zones and agglomerations into categories based on the level of air pollution; 3) air quality management (Article 15, paragraph 4 of the Regulation). Quality monitoring is carried out for the purpose of: activating protective measures in critical situations, assessing hazards for human health, assessing hazards for other elements of the environment, obtaining basic data for spatial planning, examining specific complaints of citizens (Kokić Arsić et al., 2009). The value interval of the concentration of pollutants from clean air to the limit value is a wide interval. Therefore, information that a concentration of pollutants is below the limit value is not always sufficiently precise (Jović, Knežević, MarićTanasković, Dimić, Cvetković, 2011). For a wider circle of users and the interested public, the option of a relative assessment, based on legal regulations, is more appropriate, which will characterize the state of air quality, depending on the amount of concentration of pollutants. For this type of assessment, the air quality index is applied (Jović et al., 2011). Therefore, in order to carry out the assessment of air quality, the air quality index is defined, defined by harmonization of EU domestic regulations in this field.

Since there is no uniquely defined AQI in EU regulations, the Air Quality Index SAQI_11 is defined in the Environmental Protection Agency. In the index of SAQI_11, part of the "AQI" designation is the usual indication for the air quality index, " $\mathrm{S}$ " denotes the national, Serbian version, and "11" indicates the year when the index is defined (Jović et al., 2011). The air quality index SAQI_11 has five classes depending on the concentration of certain pollutants, as follows (Jović et al., 2011): (1) when the presence of pollutants is not detected or when the concentration of the pollutant is lower than the lower Assessment boundaries - the air is clean - excellent; 2.) When the value of the concentration of the pollutant is bigger than the concentration which represents the lower limit of the assessment or less than the concentration 
which represents the upper limit of the assessment - the air is good; 3.) When the value of the concentration of the pollutant is greater than the concentration which represents the upper limit of the assessment but is not higher than the limit value - the air is acceptable; 4.) When the concentration of the pollutant is greater than the limit value, but not higher than the tolerant value - the air is contaminated; 5.) When the concentration of the pollutant is greater than the tolerant value - the air is very polluted.

The first two classes cover the range to half the limit value expressed in $\mu \mathrm{g} / \mathrm{m} 3$, the third from half to the total value of the limit value, and the values in the fourth and fifth classes are characterized by polluted air, in accordance with the provisions of the Law on Air Protection, and according to the level of air pollution. Quantitative values of concentrations of pollutants, in $\mu \mathrm{g} / \mathrm{m} 3$, for the period of averaging $24 \mathrm{~h}$ and the calendar year, according to the classes of the Air Quality Index SAQI_11, are given in the table below.

Table 1. Quantitative values of concentrations of pollutants for the period of averaging $24 \mathrm{~h}$ and the calendar year, by classes of the Air Quality Index SAQI_11

\begin{tabular}{|c|c|c|c|c|c|c|c|c|}
\hline 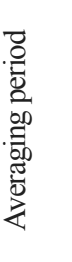 & 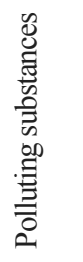 & 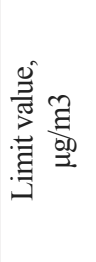 & 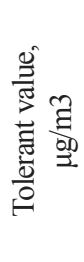 & 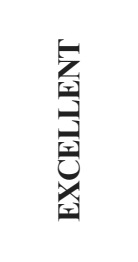 & రి & 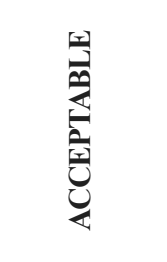 & 솔 & 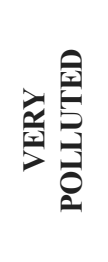 \\
\hline \multirow{6}{*}{$24 \mathrm{~h}$} & $\mathrm{SO} 2$ & 125 & & $0.0-50.0$ & $50.1-75.0$ & $75.1-125.0$ & $125.1-187.5$ & $>187.5$ \\
\hline & $\mathrm{NO} 2$ & 85 & 125 & $0.0-42.5$ & $42.6-60.0$ & $60.1-85.0$ & $85.1-125.0$ & $>125.0$ \\
\hline & PM10 & 50 & 75 & $0.0-25.0$ & $25.1-35.0$ & $35.1-50.0$ & $50.1-75.0$ & $>75.0$ \\
\hline & $\mathrm{CO}$ & 5000 & 10000 & $0.0-2500$ & $2501-3500$ & $3501-5000$ & $5001-10000$ & $>10000$ \\
\hline & $\begin{array}{c}\mathrm{O} 3-8 \mathrm{~h} \\
\text { max. }\end{array}$ & 120 & & $0.0-60.0$ & $60.1-85.0$ & $85.1-120.0$ & $120.1-180.0$ & $>180.0$ \\
\hline & soot & 50 & & $0.0-25.0$ & $25.1-35.0$ & $35.1-50.0$ & $50.1-75.0$ & $>75.0$ \\
\hline \multirow{5}{*}{ 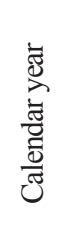 } & $\mathrm{SO} 2$ & 50 & & $0.0-30.0$ & $30.1-40.0$ & $40.1-50.0$ & $50.1-75.0$ & $>75.0$ \\
\hline & $\mathrm{NO} 2$ & 40 & 60 & $0.0-26.0$ & $26.1-32.0$ & $32.1-40.0$ & $40.1-60.0$ & $>60.0$ \\
\hline & PM10 & 40 & 48 & $0.0-20.0$ & $20.1-28.0$ & $38.1-40.0$ & $40.1-48.0$ & $>48.0$ \\
\hline & $\mathrm{CO}$ & 3000 & & $0.0-1500$ & $1501-2100$ & $2101-3000$ & $3001-4500$ & $>4500$ \\
\hline & soot & 50 & & $0.0-25.0$ & $25.1-35.0$ & $35.1-50.0$ & $50.1-75.0$ & $>75.1$ \\
\hline
\end{tabular}

Source: Jović et al., 2011; Popović et al., 2016; Popović et al., 2015; Popović et al., 2014; Popović et al., 2013; Jović et al., 2012.

In accordance with the provisions of the Law on Air Protection, and according to the level of pollution, based on the prescribed limit and tolerance values, based on the results of the measurements, the following air quality categories (Popović et al., 2016; Popović et al., 2015; Popović et al., 2014; Popović et al., 2013): 1.) The first category - pure or slightly polluted air where the limit values of the level for any pollutant are not exceeded; 2.) second category - 
moderately polluted air where the level limit values for one or more pollutants are exceeded, but tolerant values for one pollutant are not exceeded; 3.) Third category - excessively polluted air where tolerant values for one or more pollutants are exceeded.

According to Jović et al. (2011), the purpose of the existence of the Air Quality Index SAQI_11, in a situation where there are legally defined categories of air quality, is that it enables the interested public to understand the state of air quality more easily and provides more information on values less than the limit values measured in $\mu \mathrm{g} / \mathrm{M} 3$.

Table 2. Trend of air quality by zones and agglomerations for the period 2012-2015 Years

\begin{tabular}{|c|c|c|c|c|c|c|}
\hline & & \multirow{2}{*}{ Population } & \multicolumn{4}{|c|}{ Categories of air quality } \\
\hline & & & 2012 & 2013 & 2014 & 2015 \\
\hline \multirow{5}{*}{ 冬 } & The Republic of Serbia & $2,818,693$ & I & I & I & I \\
\hline & City of Kragujevac & 179,417 & & & II & III \\
\hline & City of Valjevo & 90,312 & III & III & III & III \\
\hline & Vojvodina & $1,386,830$ & $\mathrm{I}$ & $\mathrm{I}$ & $\mathrm{I}$ & $\mathrm{I}$ \\
\hline & City of Sremska Mitrovica & 79,940 & & & II & III \\
\hline \multirow{8}{*}{ 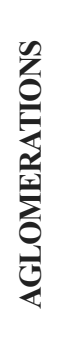 } & Novi Sad & 341,625 & $\mathrm{I}$ & I & $\mathrm{I}$ & II \\
\hline & Beograd & $1,659,440$ & III & III & II & III \\
\hline & Pančevo & 123,414 & III & $\mathrm{I}$ & $\mathrm{I}$ & III \\
\hline & Smederevo & 108,209 & III & III & III & \\
\hline & Bor & 48,615 & III & III & III & III \\
\hline & Kosjerić & 12,090 & III & II & I & \\
\hline & Užice & 78,040 & II & III & III & III \\
\hline & Niš & 260,237 & II & I & I & \\
\hline
\end{tabular}

Source: Popović et al., 2016; Popović et al., 2015; Popović et al., 2014; Popović et al., 2013.

As stated above, the Air Quality Index SAQI_11 should not be in conflict with legal provisions defining air quality categories. The first three classes of the Air Quality Index SAQI_11, "Excellent", "Good" and "Acceptable" are within the first category of air quality - pure or slightly polluted air.

The classes "Polluted" and "Highly polluted" virtually coincide with the second and third category of air quality (Jović et al., 2011). Table 1 shows shaded interpolated values. In determining class boundaries by interpolation, practically when interpolating the upper and lower bounds of pollution for pollutants for which they are not prescribed by the Regulation, the distribution pattern of those pollutants for which these parameters are determined by the Regulation is monitored. Soot is a contaminating matter whose monitoring is provided for purpose-based measurements, so it is specially marked. The SAQI_11 Air Quality Class Classes are also suitable for estimating daily values of concentrations of pollutants (Jović et al., 2011; Popović et al., 2016; Popović et al., 2015; Popović et al., 2014; Popović et al., 2013; Jović et al., 2012). For the assessment of air quality trends by zones and agglomerations for the period 2012-2015 Years, the Air Quality Index SAQI_11 is used for structural assessment of air quality in agglomerations. It determines the frequency of air quality classes based on the average daily values of concentrations of various pollutants (Popović et al., 2016; Popović et 
al., 2015; Popović et al., 2014; Popović et al., 2013; Jović et al., 2012).

By analyzing the data from Table 2, the following conclusions can be made. In the agglomeration "Novi Sad", the air is from 2012-2014. In year 2015, it was clean or slightly polluted air, while in 2015 it was switched to the second category by pollution (moderately polluted), which indicates the trend of growth of suspended particles in the last year, and, according to the concentration of polluting substances, the transition to the IV class of the Air Quality Index SAQI_11.

In the agglomeration "Belgrade", the air was excessively polluted in 2012, 2013 and 2015, and according to the concentration of pollutants, it was in the V class of the Air Quality Index SAQI_11, and only in 2014 it was moderately polluted (and according to the concentration of pollutants Matter was in the IV class of the Air Quality Index SAQI_11), which indicates the trend of reducing the growth of suspended particles during 2014.

In the „Pancevo“" agglomeration, the air was polluted in 2012 and 2015, and according to the concentration of pollutants belonged to the V Class of Air Quality Index SAQI_11, while in 2013 and 2014 it was clean or slightly polluted, indicating a trend Significant reduction in the growth of suspended particles during the above two years.

In the "Smederevo" agglomeration, the air was over-polluted from 2012 to 2014 and according to the concentration of pollutants belonged to the V Classification of the Air Quality Index SAQI_11, while in 2015 this agglomeration was not assessed.

In the "Bor" agglomeration, the air was over-polluted in all four years analyzed, and according to the concentration of pollutants belonged to the V Classification of the Air Quality Index SAQI_11, which indicates the trend of continuous emission and concentration of suspended particles in this area.

In the Kosjeric agglomeration, air pollution was excessively polluted in 2012, and according to the concentration of pollutants belonged to the SAQI_11 Air Quality Class V, it was moderately polluted in 2013 and belonged to the IV class of the Air Quality Index SAQI_11, while in 2014, Air was clean or slightly polluted, indicating a trend of decreasing the growth of suspended particles. In 2015, the agglomeration "Kosjerić" was not evaluated.

In the Uglice agglomeration, the air was moderately polluted in 2012, and according to the concentration of pollutants belonged to the IV class of the Air Quality Index SAQI_11, while in the period 2013-2015. Year was over-polluted, and it ranked in the V class of the Air Quality Index SAQI_11, which points to the trend of increasing the growth of suspended particles in this area.

In the agglomeration Nis, the air was moderately polluted in 2012, and according to the concentration of pollutants belonged to the IV class of the Air Quality Index SAQI_11, while in 2013 and 2014 it was clean or slightly polluted, indicating the trend of decrease in growth Suspended particles in this area. In 2015, the agglomeration "Nis" has not been evaluated. 


\section{Conclusion}

Sustainable rural development basically depends on the practical application of the combination of the concept of multifunctional agriculture and the development of other economic activities in accordance with the available natural and human resources, the overall improvement of living conditions, as well as the socioeconomic position of villages and rural communities (Đorđević-Milošević, Milovanović, 2012). Certainly, air quality is a very important parameter for the development of certain regions in Serbia, and sustainable rural development as a whole.

If the presented data for eight agglomerations in Serbia classified into three categories according to the level of air pollution and considering the air quality index SAQI_11, the following conclusions can be made: 1.) the agglomeration "Novi Sad" can be classified in the group of areas With predominantly pure or slightly polluted air (only in 2015 air quality was transferred to the IV class of the Air Quality Index SAQI 11), which, ecologically, is a significant potential for sustainable rural development in this area; 2.) agglomerations "Pančevo", "Kosjerić" and "Niš" can be classified in the group of areas with mostly moderately polluted air (in the agglomeration "Pančevo", the air in 2012 and 2015 belonged to the Air Quality Class V SAQI_11; In the agglomeration "Kosjerić", the air was only in 2012. in the air quality class V SAQI_11; in 2013, it belonged to the IV class of the Air Quality Index SAQI_11; in the agglomeration "Nis", the air in 2012 belonged to the IV class of the Index Air quality SAQI_11), which is, ecologically speaking, a solid potential for sustainable rural development in these areas, with the tendency of additional investments and improvements in further rural development; 3.) agglomerations "Smederevo", "Bor", "Belgrade" and "Uzice" can be classified in the group of areas with predominantly excessively polluted air (in agglomeration "Bor", the air was in the class V of theAir Quality Index SAQI_11, in the agglomeration "Smederevo", the air from 2012 to 2014 belonged to the V Air Quality Class V SAQI_11; in the agglomeration "Belgrade", the air in 2012, 2013 and 2015 belonged to the V Classification of Air Quality Index SAQI_11, While in the agglomeration of "Užice", the air in 2012 belonged to the IV class of the Air Quality Index SAQI_11, while in the period 2013-2015 it belonged to the V Classification of the Air Quality Index SAQI_11), which, ecologically speaking, is not an adequate stimulation for a sustainable rural development in these areas, and it is necessary to reduce the emission of pollutants, which will enable better ecological potential in further sustainable rural development.

\section{Literature}

1. Adinyira, E., Oteng-Seifah, S., Adjei-Kumi, T. (2007): Sustainability Assessment of Rural Development: A Review of Methodologies, In Book - Sustainable rural development: What is the role of the agri-food sector?, Vol. 39, pp. 18-27, Leibniz Institute of Agricultural Development in Central and Eastern Europe (IAMO), Halle (Saale), Germany.

1. Bogdanov, N. (2003): Rural development - EU policy, situation and perspectives in Serbia, Proceedings from the conference - Agriculture and rural development in European integration, Belgrade, The Republic of Serbia, pp. 82-91. 
2. Bogdanov N., Stojanović, Z. (2006): The methodology of rural determination and identification of rural Serbia, In Book - Agriculture and rural development of Serbia in transition period, pp. 47-70, DAES, Belgrade, The Republic of Serbia.

3. Bogdanov, N. (2007): Small rural households in Serbia and rural non-agricultural economy, UNDP, Belgrade, The Republic of Serbia.

4. Castree, N., Braun, B. (2006): Constructing rural natures, In Book - Handbook of Rural Studies, pp. 161-17, Sage Publications, London, United Kingdom.

5. Chaudhry, P., Gupta, R. K. (2010): Urban greenery and its sustainable extension strategies in hot arid region of India, International Journal of Sustainable Society, Vol. 2, No. 2, pp. 146-155, Inderscience Publishers, Olney, Bucks, United Kingdom.

2. Chmielinski, P., Chmielewska, B. (2015): Social changes in rural areas: incomes and expenditures of rural households, Economics of Agriculture, Vol. 62, No. 4, pp. 907-920, Institute of Agricultural Economics, Belgrade, The Republic of Serbia.

6. Ćirić, M., Počuča. M., Raičević, V. (2014): Level of customer orientation and customer protection in hotels in Serbia, Economics of Agriculture, Vol. 61, No. 1, pp. 25-39, Institute of Agricultural Economics, Belgrade, The Republic of Serbia.

7. Đorđević Milošević S., Milovanović J. (2012): Održivi turizam u funkciji ruralnog razvoja -Mala poljoprivredna gazdinstva i ruralni turizam u Srbiji, Fakultet za primenjenu ekologiju Futura Univerziteta Singidunum, Beograd, Republika Srbija; Agroznanje, Vršac, Republika Srbija; FAO, Budimpešta, Republika Mađarska.

8. Erokhin, V. (2014): Approaches to sustainable rural development in a predominantly non-rural region, Economics of Agriculture, Vol. 61, No. 2, pp. 291-306, Institute of Agricultural Economics, Belgrade, The Republic of Serbia.

9. Fagioli, F. F., Diotallevi, F., Ciani, A. (2014): Strengthening the sustainability of rural areas: the role of rural tourism and agritourism, Rivista di Economia Agraria, Vol. 69, No. 2-3, pp. 155-169, Firenze University Press, Firenze, Italia.

10. Ivolga, A. (2014). Overview of contemporary issues of sustainable rural development in Russia in terms of existing differences between regions, Economics of Agriculture, Vol. 61, No. 2, pp. 331-345, Institute of Agricultural Economics, Belgrade, The Republic of Serbia.

11. Yves, L. (2005): Presidential address - Rural development in Europe: A research frontier for agricultural economists, European Review of Agricultural Economics, Vol. 32, No. 3, pp. 301-317, Oxford University Press and the European Agricultural and Applied Economics Publications Foundation, The Netherlands.

3. Jović, B., Knežević, J., Marić-Tanasković, L., Dimić, B., Cvetković, I. (2011): Annual report on the air quality condition in the Republic of Serbia for 2010, Environmental Protection Agency, Ministry of Agriculture and Environmental Protection, Belgrade, The Republic of Serbia.

4. Jović, B., Marić-Tanasković, L., Knežević, J., Dimić, B. (2012): Annual report on the air quality condition in the Republic of Serbia for 2011, Environmental Protection Agency, 
Ministry of Agriculture and Environmental Protection, Belgrade, The Republic of Serbia.

12. Just, F. (2007): Rural-Urban Interlinkages and Regional Development, In Book Sustainable rural development: What is the role of the agri-food sector?, Vol. 39, pp. 3-17, Leibniz Institute of Agricultural Development in Central and Eastern Europe (IAMO), Halle (Saale), Germany.

5. Kačar, B., Curić, J., Ikić, S. (2016): Local economic development in theories of regional economies and rural studies, Economics of Agriculture, Vol. 63, No. 1, pp. 231-246, Institute of Agricultural Economics, Belgrade, The Republic of Serbia.

6. Kokić Arsić, A., Milivojević, J., Savović, I. (2009): Uticaj kvaliteta vazduha na zdravlje i kvalitet života ljudi, Proceedings from conference - Festival kvaliteta 2009-4. Nacionalna konferencija o kvalitetu života, Kragujevac, The Republic of Serbia, pp. 150-153.

13. Lowe, P., Murdoch, J., Ward, N. (1995): Networks in rural development beyond exogenous and endogenous models, In Book - Beyond modernization: The impact of endogenous rural development, Van Gorcum, Assen, Netherlands, Vol. 1, pp. 87-106.

14. Milbourne, P. (2003): Nature - society-rurality: making critical connections, Sociologia Ruralis, Vol. 43, No. 3, pp. 193-196, European Society for Rural Sociology, USA.

15. Molders, T. (2013): Multifunctional Agricultural Policies: Pathways towards Sustainable Rural Development?, International Journal of Sociology of Agriculture and Food, Vol. 21, No. 1, pp. 97-114, Research Committee of Sociology of Agriculture and Food, UK.

16. Nacionalna Strategija održivog razvoja, Službeni glasnik, Republika Srbija, no. 57/2008.

17. Papić, R., Bogdanov, N. (2015): Rural Development Policy - a perspective of local actors in Serbia, Economics of Agriculture, Vol. 62, No. 4, pp. 1079-1093, Institute of Agricultural Economics, Belgrade, The Republic of Serbia.

18. Perotto P.G. (1993): Il paradosso dell'economia; Manuale di rivoluzione cultural, Franco Angeli, Milano, Italia.

19. Popesku, J. (2008): Održivi turizam, u Brošuri - Ruralni razvoj i ruralni turizam, pp. 9-13, Agromreža, Novi Sad, Republika Srbija.

7. Popesku, J. (2011): Sustainable development of rural tourism, Taiex, Chamber of Commerce, Belgrade, The Republic of Serbia, (available at: http://www.kombeg.org.rs/ Slike/UdrTurizam/2011/novembar/TAIEX/Prezentacije/Beograd.pdf).

20. Popović, T., Knežević, J., Jović, B., Marić-Tanasković, L., Dimić, B. (2016): Annual report on the air quality condition in the Republic of Serbia for 2015, Environmental Protection Agency, Ministry of Agriculture and Environmental Protection, Belgrade, The Republic of Serbia.

21. Popović, T., Jović, B., Marić-Tanasković, L., Knežević, J., Dimić, B. (2015): Annual report on the air quality condition in the Republic of Serbia for 2014, Environmental Protection Agency, Ministry of Agriculture and Environmental Protection, Belgrade, The Republic of Serbia.

22. Popović, T., Jović, B., Marić-Tanasković, L., Knežević, J., Mitrović Josipović, M., Dimić, B. (2014): Annual report on the air quality condition in the Republic of Serbia 
for 2013, Environmental Protection Agency, Ministry of Agriculture and Environmental Protection, Belgrade, The Republic of Serbia.

23. Popović, T., Jović, B., Marić-Tanasković, L., Knežević, J., Đorđević, D., Dimić, B. (2013): Annual report on the air quality condition in the Republic of Serbia for 2012, Environmental Protection Agency, Ministry of Agriculture and Environmental Protection, Belgrade, The Republic of Serbia.

24. Ristić, L. (2013): Strategijsko upravljanje održivim ruralnim razvojem u Republici Srbiji, Ekonomski horizonti, Vol. 15, No. 3, pp. 229-243, Ekonomski fakultet Univerziteta u Kragujevcu, Kragujevac, Republika Srbija.

25. Ristić, L., Vujičić, M., Leković, M. (2016): Tourism as a factor of Ssustainable Development of rural areas belonging to Rudnička Morava, Economics of Agriculture, Vol. 63, No. 2, pp. 665-680, Institute of Agricultural Economics, Belgrade, The Republic of Serbia.

26. Sandham, L.A, Van Der Walt,A. J. (2004): Social aspects of sustainable rural development - A case study of Lepelfontein, South African Geographical Journal, Vol. 86, No. 2, pp. 68-75, Society of South African Geographers and Taylor \& Francis, United Kingdom.

27. Simonović, D. (2008): Održiva poljoprivreda i ruralni razvoj, u Brošuri - Ruralni razvoj i ruralni turizam, p. 2-9, Agromreža, Novi Sad, Republika Srbija.

28. Strategija poljoprivrede i ruralnog razvoja Republike Srbije za period 2014-2024. godine, "Službeni glasnik RS", no. 85/2014.

29. Šimkova, E. (2007): Strategic approaches to rural tourism and sustainable development of rural areas, Agricultural Economics, Vol. 53, No. 6, pp. 263-270, Czech Academy of Agricultural Sciences, Czech Republic.

30. Uredba o određivanju zona i aglomeracija, Službeni glasnik, Republika Srbija, no. 58/11 i $98 / 12$.

31. Uredba o uslovima za monitoring i zahtevima kvaliteta vazduha, Službeni glasnik, Republika Srbija, br, 11/2010, 75/2010 i 63/2013.

32. Veselinović, J., Ignjatijević, S. (2013): Pravni okvir i ekonomske mere za unapređenje agroturizma, Zbornik radova sa konferencije - Planska i normativna zaštita prostora i životne sredine, Subotica - Palić, Republika Srbija, pp. 145-150.

33. Veljković, N. (2017): Indikatori održivog razvoja: Srbija i svet, Agencija za zaštitu životne sredine, Republika Srbija, (dostupno na: http://indicator.sepa.gov.rs/o-indikatori).

34. Zakon o zaštiti vazduha, Official Gazette of RS, no. 36/2009 and 10/2013. 


\title{
KORELACIJA INDEKSA KVALITETA VAZDUHA SAQI_11 I ODRŽIVOG RURALNOG RAZVOJA U REPUBLICI SRBIJI
}

\author{
Milan Počuča $a^{4}$ Jelena Matijašević-Obradovićc ${ }^{5}$ Bojana Draškovič́ ${ }^{6}$
}

\begin{abstract}
Apstrakt
Bitan uticaj na razvoj ruralnih područja, te održivi ruralni razvoj uopšte ima kvalitet vazduha. Kvalitet vazduha je vrlo važan parametar kako za održivi ruralni razvoj, tako i za život na zemlji uopšte. U tom kontekstu zanimljivo je analizirati korelaciju održivog ruralnog razvoja i stanja kvaliteta vazduha zavisnog od iznosa koncentracije zagađujućih materija, izraženog indeksom kvaliteta vazduha SAQI_11. Osnovna pažnja u istraživanju usmerena je na analizu numeričkih vrednosti koncentracija zagađujućih materija, za period usrednjavanja - 24h $i$ kalendarsku godinu, po klasama Indeksa kvaliteta vazduha SAQI_11, te na analizu trenda kvaliteta vazduha po zonama i aglomeracijama za period 2012.-2015. godina. Zaključci o kvalitetu vazduha, klasama Indeksa kvaliteta vazduha SAQI_11, te korelaciji sa održivim ruralnim razvojem izvedeni su za aglomeracije „Novi Sad"“, „Beograd“, „Pančevo“, Smederevo “, ,Bor", „, Kosjerić“", ,Užice“ $i$,,Niš“.
\end{abstract}

Ključne reči: kvalitet vazduha, SAQI_11, zagađujuće materije, održivi ruralni razvoj.

4 Redovni profesor, dr Milan Počuča, Pravni fakultet za privredu i pravosuđe u Novom Sadu, Ulica Geri Karolja br. 1, Novi Sad, Srbija, E-mail: pocucabmilan@gmail.com.

5 Vanredni profesor, dr Jelena Matijašević-Obradović, Pravni fakultet za privredu i pravosuđe u Novom Sadu, Ulica Geri Karolja br. 1, Novi Sad, Srbija, E-mail: jela_sup@yahoo.com.

6 Docent, dr Bojana Drašković, Fakultet za graditeljski menadžment, Ulica Cara Dušana br. 62-64, Beograd, Srbija, E-mail: bodraskovic@gmail.com. 